\title{
KOMISJA WSPÓLNA RZĄDU I SAMORZĄDU TERYTORIALNEGO - W STRONĘ UPODMIOTOWIENIA SAMORZĄDU TERYTORIALNEGO
}

\section{O POTRZEBIE ZMIAN - UWAGI WPROWADZAJĄCE}

Kierunek i formy relacji władzy centralnej z samorządem terytorialnym odzwierciedlają zazwyczaj kondycję państwa i prowadzonej przez nie polityki publicznej. A ponieważ obie strony w swoim postępowaniu kierują się najczęściej odmienną racjonalnościa, przyjmują bowiem inną perspektywę (ogólnokrajowa vs. lokalna i regionalna), to wypracowanie mechanizmu konsensusu pozwalającego efektywnie realizować założone cele powinno być podstawowym zadaniem państwa opartego na decentralizacji i tę decentralizację szanującego ${ }^{1}$. Czyniąc zaś z polskiej instytucji decentralizacji zasadę konstytucyjna, jednostkom samorządu terytorialnego, wyposażonym w sądownie chroniona samodzielność, do tej pory nie zagwarantowano prawa do współdecydowania o zakresie otrzymywanych do realizacji zadań publicznych, a tym bardziej ich adekwatnego finansowania.

Przez ponad dwadzieścia lat wydawało się, że namiastką chociażby takiego forum współdziałania rządu z samorządem może być Komisja Wspólna Rządu i Samorządu Terytorialnego ${ }^{2}$, która pełniąc funkcje opiniodawczo-doradcze, mogła w pewnym zakresie wpływać na kształt procedowanych aktów prawnych dotyczących spraw samorządowych. Jeszcze cztery lata temu Igor Zachariasz, analizując funkcjonowanie Komisji Wspólnej - także w kontekście jej reorganizacji przez utworzenie komisji wspólnych działających w obszarach metropolitalnych - pisał, że stała się ona trwałym forum współpracy rządu i samorządu terytorialnego w reformie państwa oraz że „jako instytucja kohabitacji rządu i samorządu terytorialnego jest oryginalna w skali europejskiej instytucja publiczna, powstała w ramach oddolnej budowy administracji terytorialnej pod naciskiem środowisk lokalnych, instytucja, której ranga i znaczenie były na przestrzeni ostatnich 20 lat stale umacniane"”.

\footnotetext{
1 Por. Bendyk, Smolar (2019): 6-11.

2 Dalej jako: Komisja Wspólna lub KWRiST.

3 Zachariasz (2015): 24.
} 
Można by postawić tezę, że polityka rządu ostatnich czterech lat zdeprecjonowała znaczenie Komisji Wspólnej; zdecydowana bowiem większość zmian dotyczących kompetencji władz samorządowych była wprowadzana przez projekty poselskie, które nie muszą uzyskiwać opinii Komisji Wspólnej. Jednakże teza ta poddana falsyfikacji obnaża drugie, poważniejsze dno. Pomijanie Komisji Wspólnej (podobnie zresztą traktuje się Radę Legislacyjna) w procedurze legislacyjnej nie pokazuje tylko i wyłącznie słabości strony rządowej, ale pokazuje również słabość instytucjonalną samej Komisji Wspólnej, a przede wszystkim kulejącą podmiotowość jednostek samorządu terytorialnego (o kryzysie konstytucyjnym już nie wspominając).

W niniejszym artykule chcemy zmierzyć się z problemem nienależytej reprezentacji jednostek samorządu terytorialnego na poziomie państwowym, proponując takie zmiany, dzięki którym samorząd - poprzez swych przedstawicieli - otrzyma prawo głosu do współdecydowania o sobie (zarówno jeśli chodzi o organizację, zadania, jak i ich finansowanie, tak by mógł je realnie i efektywnie wykonywać). Naszym zdaniem jest to właśnie istota podmiotowości samorządu terytorialnego.

Konstrukcja artykułu przedstawia się następująco: najpierw pokrótce nakreślimy prawne ramy funkcjonowania Komisji Wspólnej, następnie dokonamy oceny pracy Komisji w latach 2015-2019, później pokażemy, w jaki sposób kraje o wysokiej kulturze politycznej rozwiązuja kwestię współpracy władzy rządowej z samorządowa, by całość zwieńczyć propozycją reformy mającej za cel upodmiotowienie samorządu terytorialnego przez upodmiotowienie Komisji Wspólnej. Pragniemy dodać, że prezentowany artykuł jest mocno rozbudowaną i poszerzoną wersją naszych rozważań zawartych w raporcie wydanym przez Fundację im. Stefana Batorego: „Polska samorządów. Silna demokracja, skuteczne państwo"4.

\section{RAMY PRAWNE FUNKCJONOWANIA KOMISJI WSPÓLNEJ}

Komisja Wspólna Rządu i Samorządu Terytorialnego jest instytucją o istotnym znaczeniu dla upodmiotowienia samorządu terytorialnego $\mathrm{w}$ systemie państwowym i w procesie decyzyjnym z zakresu prawa samorządowego. Komisja Wspólna funkcjonuje od 1993 r. ${ }^{5}$, choć pełną ustawową podstawę działalności uzyskała dopiero na skutek wejścia w życie ustawy z 2005 r. ${ }^{6}$ Ustawa określa Komisję Wspólną jako „forum wypracowywania wspólnego stanowi-

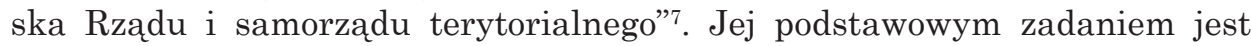

\footnotetext{
${ }^{4}$ Sześciło et al. (2019): 164-168.

${ }^{5} \mathrm{Na}$ temat genezy oraz ewolucji KWRiST od komitetu doradczego Rady Ministrów do niezależnego podmiotu - zob. Zachariasz (2015): 17-24; Gawłowski (2015): 7-13.

${ }^{6}$ Ustawa z 6 maja 2005 r. o Komisji Wspólnej Rządu i Samorządu Terytorialnego oraz o przedstawicielach Rzeczypospolitej Polskiej w Komitecie Regionów Unii Europejskiej, Dz. U. 2005, Nr 90, poz. 759. Ustawa nie była dotąd nowelizowana.

${ }^{7}$ Szerzej na temat statusu prawnego oraz zasad organizacji i działania KWRiST - zob. Izdebski (2013): 7-20.
} 
rozpatrywanie problemów związanych z funkcjonowaniem samorządu terytorialnego i z polityką państwa wobec samorządu terytorialnego, a także spraw dotyczaccych samorządu terytorialnego znajdujacych się w zakresie działania Unii Europejskiej i organizacji międzynarodowych, do których Polska należy. Aktualnie ustawa wśród zadań Komisji Wspólnej wymienia:

1) wypracowywanie wspólnego stanowiska rządu i samorządu terytorialnego w zakresie ustalania priorytetów gospodarczych i społecznych w sprawach dotyczacych gospodarki komunalnej i funkcjonowania samorządu gminnego i samorządu powiatowego oraz rozwoju regionalnego i funkcjonowania samorządu województwa;

2) dokonywanie przeglądów i ocen warunków prawnych i finansowych funkcjonowania samorządu terytorialnego, w tym także powiatowych służb, inspekcji i straży oraz organów nadzoru i kontroli nad samorządem terytorialnym;

3) ocenę stanu funkcjonowania samorządu terytorialnego w odniesieniu do procesu integracji w ramach Unii Europejskiej, w tym wykorzystywania przez jednostki samorządu terytorialnego środków finansowych;

4) analizowanie informacji o przygotowywanych projektach aktów prawnych, dokumentów i programów rządowych dotyczących problematyki samorządu terytorialnego, w szczególności przewidywanych skutków finansowych;

5) opiniowanie projektów aktów normatywnych, programów i innych dokumentów rządowych dotyczących problematyki samorządu terytorialnego, w tym także określających relacje pomiędzy samorządem terytorialnym a innymi organami administracji publicznej.

Regulamin Sejmu RP ${ }^{8}$ w art. 36 ust. 6-9 wprost wskazuje, że rozpatrywanie ustaw (uchwał), których przyjęcie może powodować zmiany w funkcjonowaniu samorządu terytorialnego, obejmuje zasięganie opinii organizacji samorządowych, tworzących stronę samorządową Komisji Wspólnej. Powyższe organizacje samorządowe mają prawo, w ciagu 14 dni od otrzymania projektu ustawy (uchwały), do przedstawienia opinii. Przedstawiciele samorządów maja prawo do zaprezentowania opinii na posiedzeniu komisji sejmowych. Paragraf 38 ust. 1 i 2 Regulaminu pracy Rady Ministrów nakazują natomiast kierowanie projektów dokumentów rządowych (np. projektów ustaw, rozporządzeń) dotyczących samorządu terytorialnego do Komisji Wspólnej w celu zaopiniowania.

Komisja Wspólna nie ma żadnych kompetencji o charakterze stanowiącym, pełni wyłącznie funkcję doradczo-opiniodawczą ${ }^{9}$. W skład Komisji Wspólnej wchodzi 12 przedstawicieli strony rządowej i 12 przedstawicieli strony samorządowej, co ma sprzyjać uzgodnieniu stanowiska. Stronę rządową w Komisji Wspólnej stanowią minister właściwy do spraw administracji publicznej oraz 11 przedstawicieli powoływanych i odwoływanych przez prezesa Rady

${ }^{8}$ Uchwała Sejmu Rzeczypospolitej Polskiej z 30 lipca 1992 r. - Regulamin Sejmu Rzeczypospolitej Polskiej, M. P. 1992, Nr 26, poz. 185 ze zm.

${ }_{9}$ Podobnie Izdebski (2013): 12. 
Ministrów na wniosek ministra właściwego do spraw administracji publicznej. Stronę samorządową w Komisji Wspólnej stanowią wyznaczeni przedstawiciele ogólnopolskich organizacji jednostek samorządu terytorialnego, w tym:

1) po dwie osoby wyznaczone przez ogólnopolskie organizacje reprezentujące następujące kategorie jednostek samorządu gminnego:

a) gminy liczące powyżej 300 tysięcy mieszkańców,

b) gminy posiadajace status miasta,

c) gminy, których siedziby władz znajdują się w miastach położonych na terytorium tych gmin,

d) gminy nieposiadające statusu miasta i niemajace siedzib swych władz w miastach położonych na terytorium tych gmin;

2) dwie osoby wyznaczone przez ogólnopolską organizację reprezentująca jednostki samorządu powiatowego;

3) dwie osoby wyznaczone przez ogólnopolską organizację reprezentująca jednostki samorządu województw.

Organizacje uprawnione do wyznaczania przedstawicieli do Komisji Wspólnej są określane w rozporządzeniu Rady Ministrów, zgodnie z delegacją ustanowiona w art. 6 ust. 4 ustawy. Rozporządzenie to wskazuje następujące organizacje: 1) Unię Metropolii Polskich; 2) Unię Miasteczek Polskich; 3) Zwiazek Gmin Wiejskich Rzeczypospolitej Polskiej; 4) Związek Miast Polskich; 5) Związek Powiatów Polskich oraz 6) Związek Województw Rzeczypospolitej Polskiej ${ }^{10}$. Członkom Komisji Wspólnej nie przysługuje wynagrodzenie.

Komisja Wspólna wyraża opinię na zasadzie jej uzgodnienia przez obie strony Komisji. Opinia może zawierać odrębne stanowiska w kwestiach szczegółowych. W przypadku braku porozumienia w sprawie uzgodnienia stanowiska każda ze stron przyjmuje własne stanowisko w sprawie będaceej przedmiotem obrad. Gdy przepisy odrębne przewiduja obowiązek zasięgnięcia opinii Komisji Wspólnej lub opinii strony samorządowej Komisji o projekcie aktu normatywnego lub innego dokumentu, termin wyrażenia opinii o projekcie wynosi $30 \mathrm{dni}$ od dnia doręczenia projektu. Nieprzedstawienie opinii w terminie oznacza rezygnację z prawa jej wyrażenia.

Członkowie Rady Ministrów oraz inne podmioty właściwe do przygotowania projektów aktów normatywnych, programów i innych dokumentów rządowych dotyczących problematyki samorządu terytorialnego przedstawiają Komisji Wspólnej do zaopiniowania projekty tych dokumentów wraz z prognozą ich skutków finansowych. Opinia Komisji Wspólnej dotycząca projektów dokumentów rządowych jest dołączana do projektu dokumentu. W przypadkach braku porozumienia w sprawie uzgodnienia stanowiska do projektu dokumentu dołącza się stanowisko każdej ze stron Komisji Wspólnej. Komisja Wspólna rozpatruje sprawy wniesione przez: 1) członków Rady Ministrów oraz inne podmioty właściwe do przygotowania aktów normatywnych; 2) współprzewodniczacych Komisji oraz 3) stałe i doraźne zespoły problemowe.

10 Rozporządzenie Rady Ministrów z 29 stycznia 2008 r. w sprawie określenia ogólnopolskich organizacji jednostek samorządu terytorialnego, które są uprawnione do wyznaczania przedstawicieli do Komisji Wspólnej Rządu i Samorządu Terytorialnego, Dz. U. 2008, Nr 15, poz. 97. 
Pracami Komisji Wspólnej kierują współprzewodniczacy: 1) minister właściwy do spraw administracji publicznej jako przedstawiciel strony rządowej oraz 2) przedstawiciel samorządu terytorialnego wybrany przez członków strony samorządowej spośród ich grona. Współprzewodniczący Komisji Wspólnej reprezentujący stronę rządową na wniosek współprzewodniczącego reprezentującego stronę samorządową lub z własnej inicjatywy może powoływać ekspertów Komisji oraz zlecać wykonanie opinii i ekspertyz na rzecz Komisji. Współprzewodniczący Komisji Wspólnej mogą zapraszać do udziału w pracach Komisji oraz jej stałych i doraźnych zespołów, z głosem doradczym, przedstawicieli administracji rządowej, samorządu terytorialnego oraz innych organizacji i instytucji. Posiedzenia Komisji Wspólnej sa protokołowane i odbywaja się w zależności od potrzeb, nie rzadziej jednak niż raz na dwa miesiące.

Komisja Wspólna powołuje stałe zespoły problemowe. Do zakresu działania stałych zespołów problemowych należy wykonywanie zadań Komisji Wspólnej w zakresie określonym przez Komisję Wspólną i przedstawianie Komisji Wspólnej wyników prac. W razie potrzeby Komisja Wspólna może powołać doraźne zespoły problemowe. Do stałych i doraźnych zespołów problemowych Komisja Wspólna może powoływać osoby spoza jej składu. Aktualnie powołano 12 stałych zespołów i jedna grupę roboczą ${ }^{11}$. Posiedzenia stałych i doraźnych zespołów problemowych odbywają się w zależności od potrzeb.

\section{OCENA PRACY KOMISJI WSPÓLNEJ W LATACH 2015-2019}

Komisja Wspólna jest organem o funkcji zasadniczo opiniodawczo-doradczej, pozbawionym własnych uprawnień władczych, stanowiących czy decyzyjnych. Oznacza to, że jedynie od woli przedstawicieli rządu zależy uwzględnienie wypracowanego w Komisji Wspólnej stanowiska odnośnie do polityki państwa względem samorządu terytorialnego.

Potencjalnie najważniejszą kompetencją Komisji Wspólnej powinno być, na gruncie obowiązujacych regulacji ustawowych, uczestnictwo w procesie legislacyjnym dotyczącym aktów normatywnych obejmujących swym zasięgiem działalność samorządu terytorialnego. Modelowo Komisja Wspólna powinna być głównym podmiotem decydującym o kierunkach zmian prawnych w tym obszarze.

W tym kontekście za niepokojące trzeba uznać zjawisko opracowywania i wnoszenia projektów ustaw ingerujących w ustrój i uprawnienia samorządu terytorialnego przez posłów związanych z aktualną większością rządząca, z pominięciem rządowego procesu legislacyjnego i inicjatywy ustawodawczej Rady Ministrów. Zjawisko to, określane powszechnie mianem „by-passowania" rządowej legislacji ${ }^{12}$, prowadzi do ominięcia znacznie bardziej gwaran-

11 Zob. informacje zawarte na stronie internetowej Komisji: <http://kwrist.mswia.gov.pl/kw/ zespoly/5621,Zespoly.html>.

12 Zob. np. Grabowska-Moroz (2016): 11. 
cyjnych przepisów regulujących tryb rządowego procesu legislacyjnego, które nakazują m.in. szerokie konsultowanie projektowanego prawa z różnymi interesariuszami, w tym Komisją Wspólną. Co więcej, projekty poselskie uchwalane były w ekspresowym trybie, nierzadko w kilka dni od ich wpłynięcia. Uniemożliwiało to zajęcie stanowiska przez środowiska samorządowe, w tym przez Komisję Wspólna, i czyniły ich rolę zupełnie marginalną. W VIII kadencji Sejmu RP w takim trybie uchwalono między innymi ustawy:

1) usprawniajaca tzw. dekomunizację nazw budowli, obiektów i urządzeń użyteczności publicznej, której projekt wniosła grupa posłów koalicji rządzącej, ustawę uchwalono w 6 dni po jej wniesieniu do Sejmu ${ }^{13}$;

2) obligująca rady gmin do ustalania, w drodze uchwały, maksymalnej liczby zezwoleń na sprzedaż napojów alkoholowych na terenie gminy oraz zasad usytuowania na terenie gminy miejsc sprzedaży i podawania napojów alkoholowych, której projekt wniosła grupa posłów koalicji rządzącej, ustawę uchwalono w 25 dni po jej wniesieniu do Sejmu ${ }^{14}$;

3) usuwajaca doradców i asystentów jako kategorię pracowników samorządowych, której projekt wniosła grupa posłów koalicji rządzącej, ustawę uchwalono w 7 miesięcy po jej wniesieniu do Sejmu ${ }^{15}$;

4) kompleksowo regulujacca warunki i tryb lokalizacji i budowy elektrowni wiatrowych oraz warunki lokalizacji elektrowni wiatrowych w sasiedztwie istniejącej albo planowanej zabudowy mieszkaniowej, której projekt wniosła grupa posłów koalicji rządzącej, ustawę uchwalono w 3 miesiące po jej wniesieniu do Sejmu ${ }^{16}$

5) przywracającą obowiązek szkolny dla dzieci od 7 roku życia, której projekt wniosła grupa posłów koalicji rządzącej, ustawę uchwalono w 20 dni po jej wniesieniu do Sejmu ${ }^{17}$.

Działalność, zadania czy nawet organizacja Komisji Wspólnej do tej pory niezmiernie rzadko były przedmiotem zainteresowania badawczego. Robert Gawłowski, analizując szczątkowe prace poświęcone Komisji Wspólnej, wyróżnił kilka problemów i postulatów związanych z jej funkcjonowaniem. Wśród nich można wspomnieć o: konieczności wzmocnienia kadrowego i merytorycznego członków Komisji przez stworzenie profesjonalnego zaplecza ekspertów potrzebie zmiany tryby pracy z sesyjnego na stały, postulacie dokonywania przez Komisję systematycznego przeglądu sytuacji funkcjonowania samorzą-

13 Ustawa z 14 grudnia 2017 r. o zmianie ustawy o zakazie propagowania komunizmu lub innego ustroju totalitarnego przez nazwy jednostek organizacyjnych, jednostek pomocniczych gminy, budowli, obiektów i urządzeń użyteczności publicznej oraz pomniki oraz ustawy o zmianie ustawy o zakazie propagowania komunizmu lub innego ustroju totalitarnego przez nazwy budowli, obiektów i urządzeń użyteczności publicznej, Dz. U. 2017, poz. 2495.

14 Ustawa z 10 stycznia 2018 r. o zmianie ustawy o wychowaniu w trzeźwości i przeciwdziałaniu alkoholizmowi oraz ustawy o bezpieczeństwie imprez masowych, Dz. U. 2018, poz. 310.

15 Ustawa z 15 września 2017 r. o zmianie ustawy o pracownikach samorządowych, Dz. U. 2017, poz. 1930.

16 Ustawa z 20 maja 2016 r. o inwestycjach w zakresie elektrowni wiatrowych, Dz. U. 2016, poz. 961 .

17 Ustawa z 29 grudnia 2015 r. o zmianie ustawy o systemie oświaty oraz niektórych innych ustaw, Dz. U. 2016, poz. 35. 
du terytorialnego i organizowania corocznej debaty ustrojowej w tym zakresie; potrzebie utworzenia regionalnych odpowiedników Komisji Wspólnej, które miałyby koordynować pracę jednostek samorządu terytorialnego i terenowych organów administracji rządowej działających na ich obszarze ${ }^{18}$; obecnym niskim stopniu realizacji zasady reprezentatywności samorządu w Komisji ${ }^{19}$; mało sprawnej organizacyjnie pracy sekretariatu strony rządowej wynikającej z niskiej instytucjonalizacji i niedoinwestowania tego organu, jak również braku środków finansowych na niezależne ekspertyzy i badania ${ }^{20}$. Uwagę zwraca również mała czytelność witryny internetowej Komisji Wspólnej ${ }^{21}$. Pomijając warstwę wizualna, ze strony tej nie można pozyskać najważniejszych i aktualnych informacji o wynikach obrad Komisji (ostatni udostępniony protokół pochodzi z posiedzenia z 25 czerwca 2018 r. ${ }^{22}$ ).

Komisja Wspólna nie jest obecnie podmiotem, który inspiruje, opracowuje i wdraża reformy prawa samorządowego. Opiniuje jedynie, i to - z uwagi na aktualną kulture polityczną - nierzadko pro forma, projekty takich zmian opracowywane przez inne organy. Jej rzeczywiste znaczenie dla kształtu prowadzenia polityki państwa w zakresie prawa samorządowego jest oceniane przez ekspertów jako marginalne, co wynika z konfliktu interesów lokalnych z rządowymi ${ }^{23}$, jak również niewątpliwie z faktu, że zakres kompetencji Komisji Wspólnej nie pozwala stronie samorządowej na stanowcze przedstawienie własnego stanowiska. Trafnie w 2013 r. problem ten ujęto w tzw. raporcie Jerzego Hausnera, w którym wskazano, że „prowadzenie [...] opracowanej i etapowej reformy [samorządu - J.P. i M.S.] wymaga wykreowania silnego i sprawnego ośrodka zarządzania. W sensie polityczno-programowym takim centrum reformy powinna stać się Komisja Wspólna” wzmocniona zespołem ekspertów z zapewnionym kilkuletnim budżetowym finansowaniem ${ }^{24}$.

\section{WSPÓŁPRACA ADMINISTRACJI SAMORZĄDOWEJ Z RZĄDOWA - PRZYKŁADY INNYCH PAŃSTW}

Swoistym paradoksem jest to, że z zagwarantowaną w art. 165 Konstytucji RP samodzielnością jednostek samorządu terytorialnego, podlegająca sądowej ochronie, w żaden sposób nie wiąże się prawo jednostek samorządu terytorialnego do współdecydowania o zmianach w zakresie nowo nabywanych przez nie zadań publicznych. Paradoks ten dodatkowo podbija fakt, że Polska jako jeden z nielicznych krajów posiada zinstytucjonalizowane - jak powinno się wydawać - ramy współpracy między samorządem terytorialnym

\footnotetext{
18 Gawłowski (2015): 11.

19 Sularz (2017): 114-128; Adamowicz et al. (2009): 27.

20 Adamowicz et al. (2009): 30-31.

${ }^{21}$ Zob. <http://kwrist.mswia.gov.pl/>.

${ }^{22}$ Informacja aktualna na 10 czerwca 2019 r.

${ }^{23}$ Opinia wyrażona przez Steca w: Adamowicz et al. (2009): 27.

24 Bober et al. (2013): 94.
} 
a władzą rządową w postaci Komisji Wspólnej właśnie; podobne instytucje funkcjonuja jedynie w Hiszpanii ${ }^{25}$ i we Francji ${ }^{26}$. Nazywamy ten stan paradoksem, w Europie bowiem sa państwa, które nie potrzebują zagwarantowanych prawnie ram współpracy, aby prowadzić usystematyzowany i konkluzywny dialog rządowo-samorządowy dotyczacy funkcjonowania samorządu terytorialnego. Doskonałym punktem odniesienia sa kraje skandynawskie.

Na przykład w Danii oraz w Norwegii wiele lat temu wprowadzono rozbudowany mechanizm konsultacji, w których udział biora strona rządowa oraz jednostki samorządu terytorialnego (w Danii reprezentuje je Krajowy Związek Gmin ${ }^{27}$, natomiast w Norwegii - Federacja Gminn ${ }^{28}$, czyli organizacje zrzeszające wszystkie jednostki samorządu lokalnego). Konsultacje te co niezmiernie ważne - odbywają się regularnie cztery raz w roku i dotyczą wszystkich niemalże kwestii związanych z szeroko rozumianymi interesami strony samorządowej. Spotkania takie - naturalnie poza wymiana poglądów odnośnie do stanu państwa i kondycji czy bieżących problemów jednostek samorządu terytorialnego - kończą się zazwyczaj wiążącą umową dwustronna między rządem a reprezentacją samorządową albo od razu autopoprawkami rządowymi do przedstawianych stronie samorządowej projektów aktów prawnych dotyczących ich funkcjonowania, albo (co rzadsze ze względu na chęć zawierania porozumień przez stronę rządowa) inicjatywą ustawodawczą strony samorządowej.

Zbliżone rozwiązania przyjęto w Szwecji, gdzie procedury konsultacji strony rządowej z Szwedzkim Stowarzyszeniem Władz Lokalnych i Regionów również nie są ściśle prawnie uregulowane ${ }^{29}$. Cechą charakterystyczną tychże konsultacji jest ich wieloaspektowość, tzn. poza opisanymi wyżej rozwiązaniami przedstawiciele Szwedzkiego Stowarzyszenia uczestniczą $\mathrm{np}$. w komitetach rządowych opracowujących projekty nowych ustaw jeszcze przed ich przekazaniem do parlamentu. Warto dodać, że Szwecja jest krajem o długiej i bogatej tradycji współpracy i konsultacji władzy centralnej z samorządowa: natomiast nieformalne kontakty i spotkania bardzo często są kluczową częścią konsultacji. Podkreślenia wymaga rzecz niezwykła z perspektywy polskiej Komisji Wspólnej - przeprowadzane konsultacje w Danii, Norwegii i Szwecji nie maja zinstytucjonalizowanych ram działania, co oznacza, że co do zasady sa one wynikiem ,jedynie” (sic!) chęci współpracy, prowadzenia dialogu, naradzania się czy uzgadniania poglądów.

Podobnie kwestię tę rozwiązano w Finlandii, wprowadzając ustawowo tzw. procedurę negocjacyjną między państwem a gminami (reprezentowanymi przez Fińskie Stowarzyszenie Władz Lokalnych i Regionalnych), w której omawiane są wszystkie sprawy dotyczące działalności administracji samorządowej oraz koordynacji finansów rządowych i samorządowych ${ }^{30}$. Niewielką

\footnotetext{
25 Adamowicz et al. (2009): 25-26.

${ }^{26}$ Gawłowski (2015): 9; Zachariasz (2015): 15, 24.

27 Council of European Municipalities and Regions (2007): 51-56.

28 Zob. <https://www.ks.no/om-ks/ks-in-english/>.

${ }^{29}$ Council of European Municipalities and Regions (2007): 211-216.

${ }^{30}$ Zob. <https://vm.fi/en/cooperation-between-the-state-and-the-municipalities>.
} 
różnicę - w porównaniu z Dania, Norwegią i Szwecją - stanowi to, że proces negocjacji został prawnie umocowany w ustawie o samorządzie lokalnym.

Przyjmujacc perspektywę polskiej Komisji Wspólnej, warto wspomnieć o regulacjach hiszpańskich, które jako jedyne w Europie przewiduja funkcjonowanie instytucji podobnej do naszej Komisji Wspólnej - mowa o Narodowej Komisji Samorządu Terytorialnego, która jest stałym organem współpracy między administracją centralną a administracją samorządową. Ponadto na poziomie wspólnot autonomicznych istnieją komisje dwustronne, komisje sektorowe oraz układy o współpracy. Stronę samorządową (obie strony mają tę samą liczbę członków) w Komisji reprezentuje Hiszpańska Federacja Gmin i Prowincji, do której podstawowych zadań należy wydawanie opinii na temat wszystkich projektów ustaw wpływających na władze lokalne i regionalne, a także np. opinii w sprawie kryteriów zadłużania się jednostek samorządu terytorialnego. Ponadto Komisja może zgłaszać własne propozycje rządowi, co jednak nie jest równoznaczne z inicjatywą ustawodawczą (choć niektórzy upatrują w tym inspirowanie takiej inicjatywy ${ }^{31}$ ), a także może zaskarżać do Trybunału Konstytucyjnego te ustawy, które jej zdaniem są sprzeczne z interesami jednostek samorządu terytorialnego.

Nie ulega najmniejszej wątpliwości, że jednostkom samorządu terytorialnego - czy to przez udział w stowarzyszeniach danych jednostek, czy to przez dodatkową instytucję w postaci Komisji - należy zagwarantować możliwość udziału w procesie legislacyjnym na etapie prac przygotowawczych danych projektów, które mają wpływ na funkcjonowanie samorządu terytorialnego. Jednostki samorządu terytorialnego, poprzez swoje reprezentacje czy Komisję Wspólna, powinny być na bieżąco informowane o proponowanych zmianach wprowadzonych w trakcie procedury legislacyjnej, tak by mogły mieć możliwość wprowadzania modyfikacji danych regulacji, a nawet by regulacje ich dotyczace nie mogły zostać zmienione bez ich zgody.

Przykłady różnych państw pokazuja, że współpraca administracji samorządowej z rządową jest elementem procesu tworzenia polityk publicznych, który nie powinien być pomijany. Formą najbardziej rozwiniętą są oczywiście te konsultacje, których efektem są wiążące obie strony umowy. Należy jednak pamiętać, że tworzenie obligatoryjnej procedury (jej charakter, tryb i zasady), powinno być osadzone również w warunkach kulturowych i społecznych. Nie da się bowiem nie zauważyć, że rozwiązania krajów skandynawskich - jako emblemat prawdziwe demokratycznej przestrzeni publicznej, w której interesariusze mają i świadomość, i chęć podejmowania współpracy, spotykania się oraz prowadzenia rozmów z poszanowaniem strony przeciwnej - są niezwykle kuszące, niekoniecznie jednak od razu do wprowadzenia w krajach wysoce scentralizowanych, ale również i w krajach o niskiej cały czas kulturze politycznej połączonej z wysokim czynnikiem interpasywności podmiotów przestrzeni publicznej ${ }^{32}$, a więc i w Polsce, gdzie bez zinstytucjonalizowanych ram działania i precyzyjnych regulacji prawnych nie można stworzyć skutecznej

\footnotetext{
31 Adamowicz et al. (2009): 26.

32 Przedańska (2009): 20-22.
} 
platformy dialogu publicznego. Dlatego też wartość prawna porozumień osiąganych w drodze konsultacji powinna zostać określona w tworzonej procedurze konsultacji (czy to przez stowarzyszone reprezentacje jednostek samorządu terytorialnego, czy przez Komisję Wspólna), tak aby obie strony - rządowa i samorządowa - były zobowiązane do przestrzegania swoich postanowień.

\section{UPODMIOTOWIENIE SAMORZĄDU TERYTORIALNEGO PRZEZ UPODMIOTOWIENIE KOMISJI WSPÓLNEJ - POSTULATY ZMIAN}

Wiążąca Polskę umowa międzynarodowa, jaką jest Europejska karta samorządu lokalnego ${ }^{33}$, wskazuje, że społeczności lokalne powinny być konsultowane o tyle, o ile jest to możliwe, we właściwym czasie i w odpowiednim trybie, $\mathrm{w}$ trakcie opracowywania planów oraz podejmowania decyzji we wszystkich sprawach bezpośrednio ich dotyczacych (art. 4 ust. 6). Postanowienie to nakazuje upodmiotowienie samorządu lokalnego w decydowaniu również o kształcie ustawodawstwa normującego jego funkcjonowanie na zasadzie „nic o nas bez nas". Trudno uznać, że uprawnienie to jest realizowane przy obecnych kompetencjach i praktyce działania Komisji Wspólnej. Z drugiej strony należy jednak wskazać, że organem odpowiedzialnym za kształtowanie polityki państwa jest Rada Ministrów, posiadająca również inicjatywę ustawodawcza, parlament zaś jest wyłącznie kompetentny do uchwalania ustaw o nieograniczonym przedmiotowo zakresie, a zatem także kształtujących status i kompetencje samorządu terytorialnego. Wynika to naturalnie z przyjętej w Konstytucji RP koncepcji podziału i równowagi władzy.

Realizując założony na wstępie cel zwiększenia znaczenia Komisji Wspólnej, uważamy, że rozwiązaniem bardziej odpowiadającym powyższym normom konstytucyjnym i prawnomiędzynarodowym byłaby modyfikacja roli ustrojowej Komisji Wspólnej z niedecyzyjnego ciała opiniodawczo-doradczego w kierunku jej wyraźnego upodmiotowienia w systemie podziału władzy, a tym samym zwiększenia partycypacji jednostek samorządu terytorialnego w zmianach prawa regulujących ich funkcjonowanie.

Zasadnicza propozycją $\mathrm{w}$ tym zakresie byłoby utworzenie $\mathrm{w}$ miejsce obecnie dwustronnej (rząd i samorząd) Komisji Wspólnej - komisji trójstronnej, obejmującej oprócz przedstawicieli strony rządowej i samorządowej również przedstawicieli władzy ustawodawczej, czyli Sejmu i Senatu. Rozwiazanie takie sprzyjałoby szerszemu kompromisowi, ale również mogłoby skutkować ograniczeniem inicjowania zmian prawnych przez grupy posłów.

W celu ograniczenia zjawiska „by-passowania” rządowej legislacji projektami poselskimi przynajmniej w obszarze prawa samorządowego, naszym zdaniem, Komisja Wspólna powinna zostać wyposażona w kompetencję do wyrażania wstępnej zgody na dalsze procedowanie w Sejmie tak wniesionego projektu ustawy. Brak takiej zgody powinien skutkować uruchomieniem

${ }^{33}$ Europejska karta samorządu lokalnego, Dz. U. 1994, Nr 124, poz. 607. 
etapu szerokich konsultacji publicznych wniesionego projektu z jednostkami samorządu terytorialnego. To swego rodzaju „opóźnianie” procesu legislacyjnego przez Komisję Wspólną mogłoby poprawić jakość i racjonalność legislacji w obszarze prawa samorządowego. Prawo uzgodnione jako kompromis w jak najszerszym gronie interesariuszy, którzy będą stosować dane regulacje, a przy tym mają rzeczywistą wiedzę dotyczącą zmienianych zagadnień, ma szanse lepiej odpowiadać potrzebom społecznym. Mogłoby to sprawić, że podmiotom dysponujacym inicjatywą ustawodawczą nie opłacałoby się opracowywać zmian legislacyjnych, które nie zyskają aprobaty Komisji Wspólnej. Odpowiednie zmiany w tym zakresie należałoby wprowadzić do Regulaminu Sejmu RP. Zmiany takie uzasadnione byłyby ochroną istotnych wartości konstytucyjnych: wyrażoną w Preambule do Konstytucji zasadą sprawności i rzetelności działania instytucji publicznych (przez wzmocnienie racjonalności i rzetelności procesu legislacyjnego w obszarze prawa samorządowego) oraz zasadzie wyrażonej w art. 16 ust. 2 Konstytucji RP, nakazującej upodmiotowienie samorządu terytorialnego w strukturze władz publicznych.

Aby móc w sposób rzeczywisty upodmiotowić Komisję Wspólna, uważamy, że powinna ona stać się główną instytucją identyfikujaccą problemy z zakresu funkcjonowania i warunków rozwoju samorządu, jak również inicjatorem projektów zmian prawnych je rozwiązujacych. W tym celu proponujemy, aby wyposażyć Komisję Wspólną w prawo inicjatywy ustawodawczej. Obecnie, zgodnie z art. 118 ust. 1 i 2 Konstytucji RP, inicjatywa ustawodawcza przysługuje jedynie posłom, Senatowi, Prezydentowi RP, Radzie Ministrów oraz grupie co najmniej 100000 obywateli mających prawo wybierania do Sejmu. W zestawieniu tym wyraźnie brakuje jednego z głównych konstytucyjnych podmiotów władzy w państwie, jakim są jednostki samorządu terytorialnego. W celu skutecznej obrony swoich interesów samorząd terytorialny powinien mieć narzędzia przynajmniej inicjujące zmiany prawodawstwa na poziomie centralnym. Zasadna idea byłoby również przyznanie prawa inicjatywy ustawodawczej określonej liczbowo grupie jednostek samorządu terytorialnego na wzór tzw. obywatelskiej inicjatywy ustawodawczej już unormowanej w Konstytucji RP. Przykładowo projekt ustawy mogłaby wnieść grupa co najmniej 15 organów stanowiących jednostek samorządu terytorialnego, tj. rad gmin, rad powiatów lub sejmików województw. Pozwoliłoby to tym jednostkom samorządu terytorialnego na zainicjowanie zmian prawnych w obszarach prawa samorządowego, które na skutek ich praktycznych doświadczeń tego wymagaja. Sprzyjałoby to jednocześnie zacieśnieniu współpracy i dialogowi między poszczególnymi jednostkami samorządu terytorialnego, które nie miałyby swojej realnej reprezentacji w Komisji Wspólnej.

Konsekwencja przyznania Komisji Wspólnej prawa inicjatywy ustawodawczej powinno być również przyznanie jej legitymacji szczególnej do występowania z wnioskiem do Trybunału Konstytucyjnego w sprawie kontroli hierarchicznej zgodności norm prawnych. Warto przy tym wskazać, że w aktualnym stanie prawnym organy stanowiące jednostek samorządu terytorialnego posiadają legitymację do zainicjowania procedury kontroli hierarchicznej zgodności norm prawnych przez TK, jeżeli kwestionowany przez nie akt nor- 
matywny dotyczy spraw objętych ich zakresem działania (art. 191 ust. 1 pkt 3 i ust. 2 Konstytucji RP).

Trzy powyższe propozycje, tj. wyposażenie Komisji Wspólnej w prawo inicjatywy ustawodawczej i prawo do występowania z wnioskiem do TK oraz wprowadzenie grupowej inicjatywy ustawodawczej dla organów stanowiących jednostek samorządu terytorialnego, wymagaja - niestety - zmiany Konstytucji. W celu ich przeprowadzenia potrzebny byłby szeroki konsensus polityczny obejmujący partię rządzącą oraz przynajmniej część partii opozycyjnych $^{34}$. Biorąc pod uwagę obecną sytuację polityczną w Polsce, wydaje się, że przedstawione postulaty mogą doczekać się realizacji dopiero w przyszłości, w szczególności z uwagi na okoliczność, iz Konstytucja RP zachowuje faktyczną sztywność i przez ponad 20 lat swojego obowiązywania została zmieniona jedynie dwukrotnie ${ }^{35}$.

Aby zwiększyć znaczenie Komisji Wspólnej w przestrzeni państwowej i tym samym sprawić, aby nie pomijano jej więcej w procesie legislacyjnym, należy zmodyfikować również skład strony samorządowej Komisji Wspólnej i sposób jego kształtowania. Przede wszystkim skład ten należy rozbudować, aby zapewnić szerszą reprezentację środowiska samorządowego, które obecnie reprezentowane jest w Komisji jedynie przez 11 osób. Dodatkowo obecny sposób wyłaniania członków Komisji Wspólnej ze strony samorządowej budzi wątpliwości z punktu widzenia realizacji zasady reprezentatywności tego gremium. Rozporządzenie Rady Ministrów arbitralnie wskazuje, że uprawnione do wyznaczania przedstawicieli do Komisji Wspólnej sa: 1) Unia Metropolii Polskich; 2) Unia Miasteczek Polskich; 3) Związek Gmin Wiejskich Rzeczypospolitej Polskiej; 4) Związek Miast Polskich; 5) Związek Powiatów Polskich oraz 6) Związek Województw Rzeczypospolitej Polskiej ${ }^{36}$. Członków Komisji wyznaczają zatem nie same jednostki samorządu terytorialnego, ale ich organizacje, będące w praktyce stowarzyszeniami. Rozporządzenie petryfikuje zatem organizacje mające prawo wyłaniania członków Komisji Wspólnej, co pozostaje w sprzeczności z ideą szerokiej reprezentacji jednostek samorządu terytorialnego w Komisji oraz demokratyzacji sposobu ich wyłaniania. Obecny sposób wyłaniania członków Komisji Wspólnej poddał celnej krytyce Paweł Sularz, wskazując, że „nieuwzględnienie przez ustawodawcę zasad reprezentatywności nie pozwala [...] zrównać organizacji JST z samorządem jako całością zjawiska ustrojowego, co rzutuje na pozycję Komisji Wspólnej, która staje się - wbrew intencjom legislatora - bliższa organowi pomocniczemu Rady Ministrów niż forum współdziałania dwóch zasadniczych konstytucyjnych elementów administracji wykonawczej”37. Zgadzamy się ze zdaniem tego autora, że obecny model Komisji Wspólnej opiera się na „swego

${ }^{34}$ Zgodnie bowiem z art. 235 ust. 4 Konstytucji RP ustawę o zmianie Konstytucji uchwala Sejm większością co najmniej $2 / 3$ głosów w obecności co najmniej połowy ustawowej liczby posłów oraz Senat bezwzględną większością głosów w obecności co najmniej połowy ustawowej liczby senatorów.

35 Na ten temat zob. np. Trzciński, Szwast (2018): 217-244 i cytowana tam literatura.

${ }^{36}$ Rozporządzenie Rady Ministrów z 29 stycznia 2008 r. w sprawie określenia ogólnopolskich organizacji jednostek samorządu terytorialnego, które są uprawnione do wyznaczania przedstawicieli do Komisji Wspólnej Rządu i Samorządu Terytorialnego, Dz. U. 2008, Nr 15, poz. 97.

37 Sularz (2017): $113 \mathrm{n}$. 
rodzaju systemie oligopolu wybranych organizacji samorządowych” i „odrzuceniu konkurencyjności, która niezbędna jest dla skutecznej ochrony interesów JST w relacjach ze stroną rządową" 38 .

Przyjmujac tę perspektywę, optymalnym rozwiązaniem byłoby zatem rozbudowanie składu Komisji np. do 60 osób, spośród których 20 reprezentowałoby stronę samorządowa, 20 - parlamentarną ${ }^{39}$ i 20 - rządową. Członkowie Komisji ze strony samorządowej powinni być wyłaniani w wyborach, w których czynnym prawem wyborczym dysponowałyby wszystkie organy stanowiące jednostek samorządu terytorialnego. Każdy ze stopni samorządu dysponowałby odpowiednia pulą mandatów do obsadzenia.

W celu przygotowania Komisji do wykonywania nowych zadań należy ja naturalnie wzmocnić pod względem organizacyjnym, finansowym i zaplecza ekspertów. Uważamy również, że Komisja Wspólna powinna pracować w trybie stałym (nie jak jest obecnie - sesyjnym). Powinny ją tworzyć osoby, dla których zasiadanie w niej nie jest zajęciem pobocznym, co niestety obecnie jest reguła. Ponadto Komisja Wspólna mogłaby - o czym dziśs w ogóle nie ma mowy, a czego zarazem bardzo brakuje w naszej przestrzeni publicznej mając zasięg ogólnokrajowy i skupiając przedstawicieli wszystkich stopni samorządu terytorialnego, być nie tylko podmiotem procesie legislacyjnym, ale przy okazji stać się platformą wymiany myśli samorządowej przez regularne organizowanie konferencji, seminariów i debat poświęconych tematyce funkcjonowania samorządu terytorialnego.

Rola Komisji Wspólnej - mogącej stanowić w aktualnym wciąż kształcie ustrojowym instrument dialogu rządu z przedstawicielami jednostek samorządu terytorialnego - nie jest obecnie ani doceniana, ani nawet brana pod uwage w procesie legislacyjnym z zakresu spraw samorządowych. Idąc krok naprzód (uważamy bowiem, że walka o utrzymanie i egzekwowanie status $q u o$, to już wyłącznie krok do tyłu), należy zagwarantować Komisji Wspólnej taką pozycję organizacyjno-zadaniowa, dzięki której będzie mogła ona stać się swoistym strażnikiem podmiotowości samorządu terytorialnego. Współdziałanie władzy centralnej ze środowiskiem samorządowym jest elementem kluczowym zdecentralizowanego państwa demokratycznego, jest to standard gwarantujący efektywną realizację zadań publicznych z poszanowaniem samodzielności upodmiotowionych jednostek samorządu terytorialnego.

Justyna Przedańska

Uniwersytet Wroctawski

justyna.przedanska@uwr.edu.pl

https://orcid.org/0000-0002-3558-3969

Michat Szwast

Uniwersytet Warszawski

https://orcid.org/0000-0001-9431-5908

m.szwast@wpia.uw.edu.pl

38 Sularz (2017): 113 n.

39 Skład strony parlamentarnej powinien odpowiadać proporcjonalnie układowi sił politycznych w Sejmie, na wzór kształtowania składu komisji sejmowych. 
Adamowicz, M., Duklewski, P., Lasota, M., Mazur, J., Mazurek, J., Rosa, A., Słowikowski, W. (2009). Współpraca administracji rządowej z administracją samorządową na przykładzie funkcjonowania Komisji Wspólnej Rządu i Samorządu Terytorialnego, [w:] M. Stec (red.), Współdziałanie administracji rządowej z administracją samorządową. Warszawa: 25-31.

Bendyk, E., Smolar, A. (2019). Nowa fala samorządności, [w:] D. Sześciło (red.), Polska samorządów. Silna demokracja, skuteczne państwo. Warszawa: 6-11. [Online: <http://www.batory. org.pl/upload/files/Programy\%20operacyjne/Masz\%20Glos/Polska\%20samorzadow.pdf>].

Bober, J. et al. (2013). Narastające dysfunkcje, zasadnicze dylematy, konieczne działania. Raport o stanie samorządności terytorialnej w Polsce. Kraków. <http://www.msap.uek.krakow.pl/ doki/publ/raport_dysfunkcje.pdf $>$.

Council of European Municipalities and Regions (2007). Consultation procedures within European states. Brussels-Paris: 51-56,211-216.<http://www.ccre.org/img/uploads/piecesjointe/filename /procedure_consultation_en.pdf>.

Gawłowski, R. (2015). Komisja Wspólna Rządu i Samorządu Terytorialnego - od konsultacji do współudziału w rządowym procesie decyzyjnym. Samorząd Terytorialny 25(12): 5-14.

Grabowska-Moroz, B. (2016). Proces legislacyjny w Polsce a gwarancje ochrony praw człowieka. $<$ http://programy.hfhr.pl/monitoringprocesulegislacyjnego/files/2013/01/Proces-legislacyjny-w-Polsce-a-gwarancje-ochrony-praw-cz\%C5\%82owieka.pdf>.

Izdebski, H. (2013). Pozycja ustrojowa Komisji Wspólnej Rządu i Samorządu Terytorialnego. Samorząd Terytorialny 23(12): 7-20.

Przedańska, J. (2009). Społeczeństwo obywatelskie jako idea filozoficzna, [w:] J. Blicharz, J. Boć (red.), Prawna działalność instytucji społeczeństwa obywatelskiego. Wrocław: 12-22.

Sularz, P. (2017). Odrzucenie zasady reprezentatywności w Komisji Wspólnej Rządu i Samorządu Terytorialnego. Dialog rząd - samorząd czy dialog rząd - organizacje jednostek samorządu terytorialnego. Przegląd Prawa Publicznego 3: 114-128.

Sześciło, D., Przedańska, J., Szwast, M., Wilk, B., Jakubek-Lalik, J., Kłucińska, P., Jakubowski, P. (2019). Demokracja samorządna, [w:] D. Sześciło (red.), Polska samorządów. Silna demokracja, skuteczne państwo. Warszawa: 164-168. <http://www.batory.org.pl/upload/files/Programy\%20operacyjne/Masz\%20Glos/Polska\%20samorzadow.pdf $>$.

Trzciński, J., Szwast, M. (2018). Formal and informal amendments to the Constitution (Poland), [w:] B. Lewaszkiewicz-Petrykowska (ed.), Rapports Polonais. XXe Congres International de Droit Compare. XXth International Congress of Comparative Law. Fukuoka, 22-28 VII 2018. Łódź: $217-244$.

Zachariasz, I. (2015). Geneza Komisji Wspólnej Rządu i Samorządu Terytorialnego. Samorząd Terytorialny 25(12): 15-24.

\section{THE JOINT COMMITTEE OF GOVERNMENT AND LOCAL SELF-GOVERNMENT - TOWARDS THE EMPOWERMENT OF LOCAL SELF-GOVERNMENT}

\section{Summary}

The Joint Committee of Government and Local Self-Government has been operating for over 25 years. It is an institution that was conceived as having an advisory capacity, as a unique instrument of dialogue between the government authority and local self-government. However, experience over the last four years has shown that the central authority has marginalized the role of the Joint Committee, ignoring it completely in the legislative process - the vast majority of changes in the powers of the self-government authorities were introduced through member bills, which do not require an opinion from the Joint Committee. In this article, the authors propose extensive reforms to empower local self-government through the empowerment of the Joint Committee. Its fundamental recommendations are to furnish the Joint Committee with the right of legislative initiative, the right to file a motion with the Constitutional Tribunal, and the introduction of a group legislative initiative to the governing authorities of local self-government units.

Keywords: Joint Committee of Government and Local Self-Government; legislative initiative; empowerment of local self-government 